\section{PATIENTS WITH CANCER AND CENTRAL PULMONARY EMBOLI TREATED SURGICALLY}

\section{To the Editor:}

We read with great interest the recent article by Greelish and colleagues, ${ }^{1}$ "Improved Midterm Outcomes for Type A (Central) Pulmonary Emboli Treated Surgically," which has the potential to change the landscape of indications for surgical intervention in acute central pulmonary embolism. The volume of acute pulmonary embolectomy cases completed at our institution would significantly increase if we used the treatment algorithm proposed. Specifically, we refer to the algorithm for patients without the classic indications for surgical intervention and moderate to severe right ventricular dysfunction according to 2-dimensional echocardiography. Currently at the Ottawa Heart Institute, our patients undergoing acute pulmonary embolectomy patients are limited to those in extremis with the classic indications outlined in by Greelish and colleagues, ${ }^{1}$ with resultant poor survival outcomes overall. If our indications for surgical intervention were to be broadened to include all those with a central pulmonary embolism and moderate to severe right ventricular dysfunction, by expanding the scope of care for this critically ill group an important associated cost burden would be placed on our already limited operating room and surgical intensive care unit resources.

\footnotetext{
The Editor welcomes submissions for possible publication in the Letters to the Editor section that consist of commentary on an article published in the Journal or other relevant issues. Authors should: - Include no more than 500 words of text, three authors, and five references. - Type with double-spacing. - See http://jtcs.ctsnetjournals.org/misc/ifora.shtml for detailed submission instructions. - Submit the letter electronically via jtcvs.editorialmanager.com. Letters commenting on an article published in the JTCVS will be considered if they are received within 6 weeks of the time the article was published. Authors of the article being commented on will be given an opportunity of offer a timely response ( 2 weeks) to the letter. Authors of letters will be notified that the letter has been received. Unpublished letters cannot be returned.
}

In light of the potential increase in surgical volume and associated resource use cost, we consider it important to eliminate additional confounders from the survival analysis. In particular the differences between the medical and surgical management groups with respect to history of cancer must be reexamined. It would be of great value to complete KaplanMeier life table analysis for both groups, excluding all patients with cancer from analysis. Active malignancy is an important confounder for all cause death rates and subsequent life table analysis. The presence of active or incurable cancer would certainly influence patient management in both subtle and overt ways, the most overt way being that a patient with metastatic or locally advanced cancer in less likely to be considered for aggressive surgical management. An additional important point is that regardless of whether patients with cancer die directly of their disease, the very presence of malignancy puts them at risk for death from other associated conditions, including thromboembolism, infection, myocardial infarction, hemorrhage, and stroke. ${ }^{2-4}$

We understand it was stated that only 1 patient in the surgical treatment group and 23 in the medically treated group died of cancer. ${ }^{1} \mathrm{We}$ still recommend that the survival analysis be completed to exclude this confounding group, however, because the presence of cancer influences patient management and puts patients at risk for death from other malignancy associated conditions. $^{2-4}$

We anticipate with great interest the results from the survival analysis excluding patients with cancer. If there is still a survival difference evident after exclusion of patients with cancer, Greelish and colleagues' article $^{1}$ truly has the potential to change the scope of surgery for acute pulmonary embolectomy by broadening our indications for surgical management.
Anna L. McGuire, $M D^{a}$ Fraser Rubens, MD, MSc ${ }^{b}$

${ }^{a}$ Division of Thoracic Surgery

University of Ottawa

${ }^{b}$ University of Ottawa Heart Institute Ottawa, Ontario, Canada

\section{References}

1. Greelish J, Leacche M, Solenkova N, Ahmad RM, Byrne JG. Improved midterm outcomes for type A (central) pulmonary emboli treated surgically. J Thorac Cardiovasc Surg. 2011;142:1423-9.

2. Inagaki J, Rodriguez W, Bodey JP. Causes of death in cancer patients. Cancer. 1974;33:568-73.

3. Ambrus JL, Ambrus CM, Mink IB, Pickren JW Causes of death in cancer patients. J Med. 1975;6 61-4.

4. Khorana AA, Francis CW, Culakova E Kuderer NM, Lyman GH, et al. Thromboembolism is a leading cause of death in cancer patients receiving outpatient chemotherapy. J Thromb Haemost. 2007;5:632-4

http://dx.doi.org/10.1016/

j.jtcvs.2012.04.018

\section{Reply to the Editor:}

We appreciate the comments of McGuire and Rubens on our article regarding the proposed new algorithm for surgical management of central surgically accessible (Vanderbilt type A) pulmonary embolism. In our article, ${ }^{1}$ we documented that active malignancy was a confounding variable for survival. Certainly, in a patient with metastatic cancer or locally advanced malignancy, the decision to proceed with aggressive surgical management should be undertaken only after careful consideration. In our study, among patients treated surgically, 2 had active malignancy and 1 died during follow-up as a result of the cancer. In the medically treated group, the incidence of cancer at the time of diagnosis of pulmonary embolism was higher but not significantly so $(32 \%$ vs $13 \% ; P=.135)$. Had we excluded all patients with a diagnosis of cancer at the time of diagnosis of pulmonary embolism, we would have excluded 34 patients (32 in the medical group and 2 in the surgical group), leaving for analysis a very small 
number of patients, especially in the surgical group $(\mathrm{n}=13)$.

Exclusion of patients with cancer at the time of pulmonary embolism, however, is more complicated than performing a Kaplan-Meier survival analysis with fewer patients at follow-up. There are several different types of cancer, of course, and the survival and prognosis are influenced not only by the type of cancer (Hodgkin lymphoma vs pancreatic cancer for example) but also by the staging (localized vs metastatic), the overall condition of the patient, and the patient's age. We agree with McGuire and Rubens that a patient with metastatic cancer will likely have a very poor prognosis and probably should not undergo aggressive surgery for pulmonary embolism, and this is an assessment that should be performed by the surgeon, the patient, and the family at the bedside. If, however, a patient has a history of cancer that has been treated successfully with surgery, chemotherapy, or radiation therapy and as a result has a meaningful survival ( $>1$ year), then surgery for pulmonary embolism should be carefully considered. In general, for patients with known diagnosis of cancer at the time of pulmonary embolism, our practice is to consult our medical oncology colleagues, when patient stability makes this feasible, to give us an assessment of the estimated survival. If survival is estimated at greater than 1 year, we consider pulmonary embolism surgery and go over this with the patient and family.

Marzia Leacche, $M D$

John G. Byrne, MD

Vanderbilt Heart \& Vascular Institute Nashville, Tenn

\footnotetext{
Reference

1. Greelish JP, Leacche M, Solenkova N, Ahmad RM, Byrne JG. Improved long-term outcomes for type A (central) pulmonary emboli treated surgically. $J$ Thorac Cardiovasc Surg. 2011;142:1423-9.

http://dx.doi.org/10.1016/ j.jtcvs.2012.05.064
}

\section{THE PARACHUTE TECHNIQUE FOR ANTERIOR LEAFLET PROLAPSE \\ To the Editor:}

The publication by Zannis and colleagues ${ }^{1}$ highlights the critically important new surgical approach for the treatment of anterior leaflet prolapse. Konstantinos and colleagues performed the parachute technique on 44 consecutive patients. ${ }^{1}$ Echocardiographic examination was performed in all patients to measure the distance from the tip of each papillary muscle to the annular plane at end systole in an apical view. Constructing the parachute according to the described distance may cause the persistence of prolapse because there must be coaptation depth between the anterior and posterior leaflets. ${ }^{2}$ The coaptation depth is approximately $4 \mathrm{~mm}$ in the anterior and posterior commissures and approximately $8 \mathrm{~mm}$ between the A2 and P2 scallops. Adjusting the coaptation depth is not clear in the article.

Furthermore, the authors did not mention the causes of the patient's disease. The artificial chordal replacement can be used in both Barlow's disease and fibroelastic deficiency. ${ }^{3}$ Nonetheless, Barlow's disease has distinct features. It generally has complex valve pathology and dysfunction, which is most often multisegmental. Lesions include excessively thick and billowing leaflet segments, chordal elongation and chordal rupture, calcification of the papillary muscles or annulus with chordae restriction, and severe annular dilatation with giant valve size. ${ }^{4}$ Patients with fibroelastic deficiency often present with minimal, as opposed to excess, tissue, so extensive leaflet resection or complex leaflet remodeling procedures are rarely indicated. ${ }^{4}$ All lesions present should be corrected to store not only valve competency but also a normal valve geometry and satisfactory line closure. Because excess tissue is the hallmark lesion of Barlow's disease, leaflet resection and restoration of normal relationship of the annular dimension are usually central to the surgical strategy. ${ }^{4,5}$ The authors state that in the beginning of their experience, large anterior mitral leaflet prolapses had been addressed by triangular resection of some of the excess tissue before parachute implantation. In the perennial concern of simplification and standardization of surgical techniques, they have completely abandoned anterior mitral leaflet triangular resection, and the running suture was used to crimp excessive tissue on the Dacron strip of the parachute. ${ }^{1}$ However, crimping may only remove the excess tissue vertically, not horizontally. So performing triangular resection in the anterior leaflet may improve the result in selected cases.

This is an admirable study. The readers thank the authors for sharing their experience and knowledge. The explanation of previously described points will be helpful for better understanding.

$$
\begin{array}{r}
\text { Murat Tavlasoglu, MD } \\
\text { Department of Cardiovascular } \\
\text { Surgery } \\
\text { Diyarbakir Military Medical Hospital } \\
\text { Diyarbakir, Turkey }
\end{array}
$$

\section{References}

1. Zannis K, Mitchell-Heggs L, Di Nitto V, Kirsch ME, Noghin M, Ghorayeb G, et al. Correction of anterior mitral prolapse: the parachute technique. J Thorac Cardiovasc Surg. 2012;143(4 Suppl):S24-8.

2. Carpentier A, Adams DH, Filsoufi F. Surgical anatomy and physiology. In: Carpentier's Reconstructive Valve Surgery. St Louis, MO: Saunders; 2010:31.

3. Rankin JS, Orozco RE, Rodgers TL, Alfery DD, Glower DD. "Adjustable" artificial chordal replacement for repair of mitral valve prolapse. Ann Thorac Surg. 2006;81:1526-8.

4. Anyanwu AC, Adams DH. Etiologic classification of degenerative mitral valve disease: Barlow's disease and fibroelastic deficiency. Semin Thorac Cardiovasc Surg. 2007;19:90-6.

5. Carpentier A, Adams DH, Filsoufi F. Degenerative valvular disease. In: Carpentier's Reconstructive Valve Surgery. St Louis, MO: Saunders; 2010:270-5.

http://dx.doi.org/10.1016/ j.jtcvs.2012.03.085

\section{Reply to the Editor:}

In this patient series, ${ }^{1}$ we report our experience regarding the correction of 